University of South Carolina

Scholar Commons

Faculty Publications

Information Science, School of

$7-10-2020$

\title{
Struggling to Breathe: COVID-19, Protest, and the LIS Response
}

Amelia N. Gibson

University of North Carolina at Chapel Hill

Renate Chancellor

Catholic University

Nicole A. Cooke

University of South Carolina, Ncooke@mailbox.sc.edu

Sarah Park Dahlen

St. Catherine University, spdahlen@illinois.edu

Beth Patin

Syracuse University

See next page for additional authors

Follow this and additional works at: https://scholarcommons.sc.edu/libsci_facpub

Part of the Library and Information Science Commons

\section{Publication Info}

Preprint version Equality, Diversity and Inclusion, 2020.

(C) 2020 Equality, Diversity and Inclusion, Emerald Insight

This Article is brought to you by the Information Science, School of at Scholar Commons. It has been accepted for inclusion in Faculty Publications by an authorized administrator of Scholar Commons. For more information, please contact digres@mailbox.sc.edu. 


\section{Author(s)}

Amelia N. Gibson, Renate Chancellor, Nicole A. Cooke, Sarah Park Dahlen, Beth Patin, and Yasmeen Shorish 

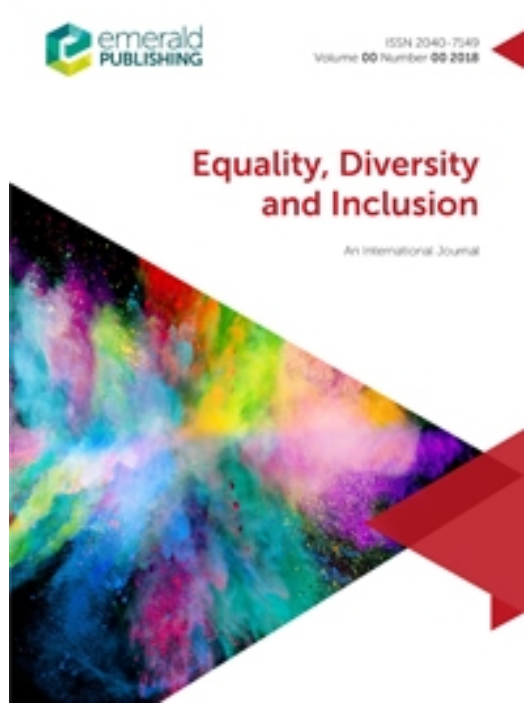

\section{Struggling to Breathe: COVID-19, Protest, and the LIS Response}

\begin{tabular}{|r|l|}
\hline Journal: & Equality, diversity and inclusion: An international journal \\
\hline Manuscript ID & EDI-07-2020-0178.R1 \\
\hline Manuscript Type: & Professional Insights \\
\hline Keywords: & $\begin{array}{l}\text { Black People, Ethnic minorities, Occupational health and safety, Public } \\
\text { sector organizations, Protest, Libraries }\end{array}$ \\
\hline \multicolumn{2}{|l}{} \\
\hline
\end{tabular}

\section{SCHOLARONE ${ }^{m}$ \\ Manuscripts}




\section{Introduction}

We've spent a lot of time thinking about breath lately. Three years ago, we wrote, here, about Black Lives Matter within the context of libraries and information science (LIS) (Gibson et al., 2017). We wrote, then, that communities of color were in crisis and living in terror and talked about the history and responsibilities of libraries -as social and political infrastructure, and as spaces for developing communal knowledge and facilitating community action. We wrote about the dangers of neutrality and how the concept of neutrality is often used to support status quo in information organizations and to ignore the work of movements like the Movement for Black Lives. And then we watched for three years, as our institutions failed to respond to increasing threats on communities of color, LGBTQIA+ folks, and disabled folks, claiming "neutral" positions on questions of safety and existential threat for Black people, Indigenous people and other people of color (BIPOC) and others. We watched continued debates over white supremacists meetings in libraries (LaRue, 2018), protection of trans people ("revoke the Library of the Year 2020 award," n.d.), and whether Confederate statues were more important than living, breathing Black people (Palmer and Wessler, 2018).

In February of 2020, 25 year-old Ahmaud Arbery was jogging near his home, when he was shot and killed by three white men whose "instincts" told them that he was a thief (Fausset, 2020).

COVID-19 first introduced itself to the world as a respiratory disease. By the time we realized that it would not just "go away" (Washington Post n.d.), it had spread up and down the Western United States and was quickly taking hold in large and small cities across the country. By March of 2020, most of the United States - like most of the world - was shut in, trying to slow the progress of a disease that could hang in the air and smother us slowly. 
On March 13, Breonna Taylor, a 26-year old EMT was shot 8 times in her home by plainclothes officers executing a nighttime no-knock warrant (Jr and Taylor, 2020). The warrant was for another person, in another home (miles away), who was already in police custody.

Millions of Americans found themselves out of work or furloughed as COVID-19 pushed states to shut down. Libraries, schools, and universities across the country closed their doors to public traffic. Many low-income workers (many who were Black and Latinx) were labeled "frontline" or "essential" - ineligible to work from home (Kendi, 2020), and many others simply could not afford to stop working in high risk, high contact positions. Soon, the effects of a one-time federal stimulus payment began to wear off (Werner and DeBonis, 2020). With limited financial support from federal and state governments, extended stay-at-home orders, and the president vocally complaining about COVID shut-downs (Associated Press, 2020), frustration and tension began to boil over. While lockdown protests occurred globally, protests in the U.S. took on a particular racial and political dimension. The news showed mostly white, armed groups storming streets and statehouses around the country ("Armed lockdown protesters in Michigan statehouse," 2020; Fernandez and Montgomery, 2020). We saw image after image of stoic police officers, doctors, and nurses quietly facing screaming protestors who wore firearms, but no masks. In response to this pressure, and despite rising infection and hospitalization rates in much of the country, many public and private institutions soon began to "open," dismantling protections for workers.

On May 25, George Floyd was killed by a police officer in Minneapolis in front of a convenience store (Taylor, 2020). The officer kneeled on Mr. Floyd's neck for almost 9 minutes, ignoring his pleas for help. His killing, recorded and shared across the country, echoed a cry that many Black people in the U.S. know well - "I can't breathe." 
Many Black people could see parallels between disproportionate COVID-19 hospitalizations and deaths (CDC, 2020) at the hands of institutions that considered their lives to be acceptable sacrifices for jump-starting the economy, and deaths at the hands of police officers and "vigilantes" who considered them acceptable sacrifices for the maintenance of a one-sided "order."

The next day, protests began in Minneapolis and spread around the world.

\section{Institutions rush to speak}

Police responses to the protests were swift and violent, drawing further condemnation domestically and abroad. In response, many pubic-facing learning and information institutions began to issue statements in early June. These statements ranged from general affirmations that 'racism is bad and diversity is good'(Hlywak, 2020a) to specific indictments against police brutality (Sellie, 2020) and historically contextualized reflections (Oakland Public Library Racial Equity Team, 2020). Non-exhaustive lists of these statements have been compiled by American Library Association (ALA) past-president Loida Garcia-Febo (2020) and InfoDocket (Price, 2020).

Libraries were not the only organizations to issue sympathetic but sometimes solipsistic statements of support. Many corporations, universities, and non-profits also issued statements that appeared to focus more on reputation management than on attempts to learn how institutional racism manifests, or any concrete plans for action to protect their workers and communities (Graves and Jarvis, 2020). Many were so focused on the optics of protest that they could not see the connections between workplace protections for Black workers who were disproportionately affected by COVID-19 and the Movement for Black Lives. While some 
libraries have included explicit actions and resources in their statements (JMU Libraries, 2020; Mudrock, 2020), it is unclear how many addressed specific issues, like anti-racist values, institutional complicity in systemic white supremacy, and long-term plans for action and accountability.

Reactions to these statements have been mixed. In private correspondence, several BIPOC information workers have remarked that their organizations were eager to issue statements but have not worked to create anti-racist cultures or dismantle internal cultures of white supremacy. Others felt tokenized, mentioning that they had been asked to help craft these statements only because of their ethnic or racial identities, and on very short timelines. Additionally, many BIPOC library workers, familiar with the historic and continual centering of whiteness in the profession (Westbrooks, 2020) and the fleeting and fragile nature of white attention to racial issues, hesitated to take on the risk of crafting authentic messages.

While the multitude of statements may have helped start conversations about white supremacy in the field, institutions must commit to action and accountability if they want to make change. In the words of Nancy S. Kirkpatrick (OhioNET Executive Director and CEO), "Show us, don't tell us" (Kirkpatrick, 2020). Organizations should ask, "Why make this statement now? What do we hope to accomplish? What hard truths and uncomfortable reckonings are we prepared to face?" Many fear this recent rush of goodwill has largely been performative and will be short-lived, but if it has opened the door to progress, we welcome the opportunity for meaningful change.

\section{No neutral ground}

When discussing issues of racial justice, there is no neutral ground. As Dr. King said, "To ignore evil is to become an accomplice to it" (King, Jr., 1966). Ray (2019) posits that many 
organizations, despite frequent claims of "race-neutral bureaucratic structures" operate under racial ideologies that can be divined by examination of the organization's rules and resources (or power structures). LIS - like some other fields - has long used the concept of neutrality as cover for ignoring and reproducing white supremacist policies and organizational structures (Bourg, 2014; Gibson et al., 2017; Hathcock, 2015).

During the 2018 annual meeting, the ALA Presidential Program included a debate over the question: Are Libraries Neutral? James LaRue, former director of the ALA's Office of Intellectual Freedom defined neutrality as "the refusal to deny people access to a shared resource just because we don't like the way they think" (LaRue, 2018). While it seemed reasonable on its face, LaRue's definition sidestepped questions about contemporaneous (and contemporary) threats of violence against community members. LaRue's assertion that neutrality assures everyone "a seat at the table" assumes that there are 'very good' people on both sides of the table and ignores existential threats like violence and risk of serious illness.

Library and Information Science's complicity in supporting and creating oppressive and racist laws and policies have implicated the field in the "history of the United States [as] a history of settler colonialism, of slavery, of segregation, and of state-sponsored discrimination" (ALA, 2018). How does this history of oppression play out today? From policy to programming to people, libraries, information organizations, and companies that build information systems are uniquely positioned to inflict structural violence on BIPOC. They continue to do so by claiming "neutrality" while creating surveillance, educational, and health care systems that disproportionately harm BIPOC communities. 
We are hopeful that this moment pushes library and information organizations to embrace a stance focused on social responsibility (Phenix and McCook, 2005). What could the nation's future look like if the profession tasked with teaching children and adults about information, misinformation, media literacy, data and science literacy eschewed the myth of institutional neutrality, adopted anti-racist practices, and empowered oppressed members of our communities? In his Nobel Peace Prize acceptance speech, Elie Wiesel tells us: "We must take sides. Neutrality helps the oppressor, never the victim. Silence encourages the tormentor, never the tormented. Sometimes we must interfere" (Wiesel, 1986). Three years ago, we asked for an institutional response to support marginalized communities. LIS has failed to give a meaningful response, claiming "neutrality" instead. We hope that this moment has made it clear that we cannot and must not claim that libraries for everyone while upholding racist and oppressive systems. The time has come to interfere.

\section{More than a Trend}

The deaths of Ahmaud Arbery, Breonna Taylor, and George Floyd have elicited new levels of fervor and rage from people, many of whom appear to be recognizing and acknowledging racism, systemic oppression, Black Lives Matter, and police brutality for the first time. It's difficult to pinpoint exactly why these three deaths ignited a need for change, as Black deaths at the hands of police have been innumerable and have "gone viral" on social media in the past. Perhaps the COVID-19 global pandemic created a perfect storm, facilitating this new wave of personal revelations. But will these new convictions be long-lasting or is this just a trend that will dissipate in a few months?

The number of anti-racist resources and calls for anti-racist action that emerged immediately after George Floyd's death was staggering. And then, after a few weeks, social media feeds 
began to return to "normal," with fewer requests for recommendations. Perhaps those quick readings of Di'Angelo's White Fragility and Kendi's How to be Anti-Racist did the trick? We know that antiracism work is not, and has never been, that simple. The stakes are high and sparks of outrage can only carry us so far. Anti-racism work takes time, effort, and intentionality (Cooke, 2020); it's a long game, and reading and increasing awareness are only the first step. Learners, who will hopefully develop into allies, must also develop a critical consciousness ${ }^{1}$, and then must commit to action.

Libraries and ALA have the opportunity to take action and to demonstrate that this moment is more than a passing fad. On June 26, 2020, the American Library Association released a statement entitled ALA takes responsibility for past racism, pledges a more equitable association, acknowledging that the ALA was built on "systemic racism and discrimination," and recognizing "hurt and harm done to BIPOC library workers and communities due to these racist structures" (Hlywak, 2020b). On the same day, Black employees at the Free Library of Philadelphia sent an open letter to their administration complaining that they have routinely experienced racism and discriminatory treatment in the workplace. We are eager to see how their administration (and, more broadly, the ALA) will respond. Will they fulfill their pledge to create a more equitable organization? Or will they need to wait for the next antiracism trend to act?

\begin{abstract}
At what cost?
${ }^{1}$ Developing a critical consciousness involves the recognition of system inequities and being aware of the damage these inequities over time.
\end{abstract}


Anti-racism protests are not the only equity issue facing LIS at this moment. Resurgences of COVID-19 in many states continue to threaten the nation, putting disabled and chronically ill, older, and BIPOC "frontline" workers (such as library workers who interface with the public) at increased risk for hospitalization and death. According to the CDC, "non-Hispanic black persons, Hispanics and Latinos, and American Indians/Alaska Natives, evidence points to higher rates of hospitalization or death from COVID-19 than among non-Hispanic white persons"(CDC, 2020).

Public-facing institutions have had to confront decisions about when to open their doors and how to provide services while maintaining appropriate protective measures. The ALA surveyed 3,800 libraries across the 50 states and found that $37 \%$ plan to reopen by July, while $47 \%$ do not have plans to open anytime soon (ALA, 2020). Many libraries have started bringing their employees back from work-at-home arrangements and furloughs to offer public-facing services like curbside lending, librarian consultations by appointment, and computer and technology services. Several employees have expressed anger about returning to work because of preexisting health issues, dangers to vulnerable family members, and general concerns about contracting the disease. To make library re-openings possible, librarians have had to implement new safety protocols, such as quarantining materials and offering curbside services (Harris, 2020). Even so, many have expressed that the return to library buildings, with the country still at a height of the pandemic, is too much, too soon.

It isn't clear that policymakers and institutional leader understand workers' realities on the ground. In April, a report for governors on reopening issued from Johns Hopkins University 
initially described libraries as "a low-risk environment, meaning contact with other people is brief, 'fairly distant' and with a few people" (Poon, 2020). The report provoked such a hostile response from librarians that it was eventually revised (Rosenbaum, 2020). Callan Bignoll, the director of the library at Olin College of Engineering commented, "they're thinking libraries are quiet and chill, with airy reading rooms where people just grab books off the shelves and don't interact with each other. That is absolutely not the case." The report later reclassified libraries as medium to high risk when they function as "community centers" (Poon, 2020).

Epidemics and pandemics like COVID-19 are known to expose fundamental racial and socioeconomic inequities (Link and Phelan, 1995). As protests against anti-Black racial violence and extrajudicial killings continue, the connections between these two pandemics becomes clearer. COVID-19, which has caused the deaths of over 130,000 Americans to date, has been fed by the same racism and disregard for life as the racism that killed George Floyd over a $\$ 20$ bill. The same value system that prioritizes property over people in policing justifies the collateral deaths of people of color, poor people, and disabled and chronically ill people for economic growth. As COVID-19 hospitalization rates begin to rise, we are learning that there is a universal cost to sacrificing our most vulnerable. As the country pushes to reopen, we should ask ourselves, what is the risk and to whom?

\author{
Possibilities for Pan-ethnic Solidarity: Asian Americans and the Movement for Black Lives \\ The global Movement for Black Lives has seen a groundswell of support over the past month as \\ protests have expanded beyond the U.S., Canada, and the U.K. (Thousand Currents, n.d.) to \\ countries all over the world (Dalton, 2020). Within a couple of weeks after the killing of George
}


Floyd, protests had also sprung up in Australia (Regan et al., 2020), South Africa (O'Dowd and Hagan, 2020), the Republic of Korea ("Rally held in central Seoul to support Black Lives Matter movement," 2020), and many other countries. This support has been echoed by calls for panethnic solidarity within the United States.

The history of relations between Asian Americans and Black Americans in the U.S. is long and complicated (Lang, 2020). This recent movement toward solidarity with Black communities in Korean American (and Korean) communities presents a sharp contrast to the anti-Black sentiment widely held before, during, and after many previous protest movements, such as the 1992 Los Angeles uprisings. Support for the Movement for Black Lives has extended quickly into popular culture in and outside of Korea.

The current situation is further complicated by the fact that one of the four police officers charged with George Floyd's murder is Hmong. Prominent Asian Americans have disagreed on whether (and how much) Tou Thao's Asianness implicates Asian American communities as complicit in upholding white supremacy and perpetuating anti-Blackness (Kang, 2020; Westerman et al., 2020; Yang, 2020). It is becoming clearer, however, that institutionalized white supremacy harms us all, and we need a shared movement to dismantle it. With ongoing police brutality, the detention of families along the southern border, ongoing threats to Indigenous sovereignty, and the resurgence of anti-Asian racism during the COVID-19 pandemic, Asian American communities should take this opportunity to help build a stronger, broader, pan-ethnic movement to dismantle white supremacy. 
This need exists within LIS programs as well. While Asian and Asian American faculty are statistically well-represented in LIS programs, few actually teach and research on topics related to racism and white supremacy; hopefully this current moment motivates them to educate themselves in earnest so that they may be more anti-racist in teaching and research. While LIS programs talk at length about multiculturalism and diversity, their reluctance to confront racism has largely left the field unable to recruit and retain BIPOC faculty (Cooke, 2019; Gibson and Hughes-Hassell, 2017), students, or library practitioners - a testament to its white supremacist culture (Hathcock, 2015; Honma, 2005). Asian and Asian American LIS faculty must familiarize themselves with work written by other colleagues of color (e.g., We Here, 2020), and resources that help us understand and interrogate institutional, structural, and individual racism (e.g., Cooke, 2020). Faculty must educate students and communities about the histories of racism, white supremacy, and anti-Blackness, specifically but not only in LIS, and present case studies of librarians who are activating on behalf of and together with their communities. Students and data scientists should use their skills and expertise to track trends in police brutality, the spread of anti-Asian racism, and other social issues. We can look to previous panethnic movements as models: the solidarity among Asian and Latinx farm workers in California; the Third World Liberation Front demanding ethnic studies at San Francisco State University; and the diverse coalition fighting for justice for Vincent Chin.

\begin{abstract}
As anti-Asian racism punctures the myth of the Model Minority and as more people realize that in fact Black Lives do Matter, LIS professionals must reflect on the gaps in our knowledge and the steps we must take to ensure that we are working together to dismantle white supremacy. Our communities are in crisis. We need each other.
\end{abstract}




\section{References}

ALA, 2020. Moving Forward: Key Findings from New Libraries' COVID-19 Response Survey: Re-opening \& Financial Results. American Library Association.

Armed lockdown protesters in Michigan statehouse, 2020. . BBC News.

Associated Press, 2020. 'Our Country Wasn't Built to Be Shut Down,' Trump Says.

Bourg, C., 2014. The unbearable whiteness of librarianship. Feral Librarian. URL https://chrisbourg.wordpress.com/2014/03/03/the-unbearable-whiteness-of-librarianship/ (accessed 7.8.20).

CDC, 2020. COVID-19 in Racial and Ethnic Minority Groups | CDC [WWW Document]. URL https://www.cdc.gov/coronavirus/2019-ncov/need-extra-precautions/racial-ethnicminorities.html (accessed 6.30.20).

Cooke, N., 2020. Reading Is Only a Step on the Path to Anti-Racism [WWW Document]. PublishersWeekly.com. URL https:/www.publishersweekly.com/pw/by-topic/industrynews/libraries/article/83626-reading-is-only-a-step-on-the-path-to-anti-racism.html (accessed 6.30.20).

Cooke, N.A., 2019. Impolite Hostilities and Vague Sympathies: Academia as a Site of Cyclical Abuse. Journal of Education for Library and Information Science 60, 223-230. https://doi.org/10.3138/jelis.2019-0005

Dalton, J., 2020. Black Lives Matter protest held in London | The Independent [WWW Document]. URL https://www.independent.co.uk/news/uk/home-news/black-livesmatter-london-george-floyd-protest-demonstrationa9541066.html?fbclid=IwAR0oVWo5ryc0n1yWM41MOIWFRYt_TM39iBVpfEdePIpc z7XWzBauAOzbBAM (accessed 6.30.20).

Fausset, R., 2020. What We Know About the Shooting Death of Ahmaud Arbery. The New York Times.

Fernandez, M., Montgomery, D., 2020. Businesses Chafing Under Covid-19 Lockdowns Turn to Armed Defiance. The New York Times.

Garcia-Febo, L., 2020. Black Lives Matter: Statements \& Resources. IFLA CPDWL Blog. URL http://blogs.ifla.org/cpdwl/2020/06/16/black-lives-matter-statements-resources/ (accessed 6.30.20).

Gibson, A.N., Chancellor, R.L., Cooke, N.A., Park Dahlen, S., Lee, S.A., Shorish, Y.L., 2017. Libraries on the frontlines: neutrality and social justice. Equality, Diversity and Inclusion: An International Journal 36, 751-766. https://doi.org/10.1108/EDI-11-2016-0100

Gibson, A.N., Hughes-Hassell, S., 2017. We Will Not Be Silent: Amplifying Marginalized Voices in LIS Education and Research. The Library Quarterly 87, 317-329. https://doi.org/10.1086/693488

Graves, J., Jarvis, E., 2020. An Open Letter: Scientists and Racial Justice [WWW Document]. The Scientist Magazine ${ }^{\circledR}$. URL https://www.the-scientist.com/news-opinion/an-openletter-scientists-and-racial-justice-67648 (accessed 6.30.20).

Harris, E.A., 2020. Libraries Strive to Stay 'Community Living Rooms' as They Reopen. The New York Times.

Hathcock, A., 2015. White Librarianship in Blackface: Diversity Initiatives in LIS - In the Library with the Lead Pipe. URL /2015/lis-diversity/ (accessed 6.30.20). 
Hlywak, S., 2020a. ALA Executive Board stands with BCALA in condemning violence and racism towards Black people and all People of Color [WWW Document]. News and Press Center. URL http://www.ala.org/news/press-releases/2020/06/ala-executive-boardstands-bcala-condemning-violence-and-racism-towards-0 (accessed 6.30.20).

Hlywak, S., 2020b. ALA takes responsibility for past racism, pledges a more equitable association [WWW Document]. News and Press Center. URL http://www.ala.org/news/press-releases/2020/06/ala-takes-responsibility-past-racismpledges-more-equitable-association (accessed 6.30.20).

Honma, T., 2005. Trippin' Over the Color Line: The Invisibility of Race in Library and Information Studies. InterActions: UCLA Journal of Education and Information Studies 1.

JMU Libraries, 2020. A Pledge: Self-Examination and Concrete Action in the JMU Libraries : JMU Libraries [WWW Document]. URL https://www.lib.jmu.edu/a-pledge-selfexamination-and-concrete-action-in-the-jmu-libraries/ (accessed 6.30.20).

Jr, R.A.O., Taylor, D.B., 2020. Here's What You Need to Know About Breonna Taylor's Death. The New York Times.

Kang, J., 2020. Tou Thao and the Myths of Asian American Solidarity. Time to Sat Goodbye. URL https://timetosaygoodbyepod.substack.com/p/tou-thao-and-the-myths-of-asianamerican?fbclid=IwAR00pK2yS89wZqtBtUCg6CQocSi7URufmrCxAeC54qZZnlv4o5KmabemCY

Kendi, I.X., 2020. Stop Blaming Black People for Dying of the Coronavirus [WWW Document]. The Atlantic. URL https://www.theatlantic.com/ideas/archive/2020/04/race-andblame/609946/ (accessed 6.30.20).

King, Jr., M.L., 1966. Martin Luther King and Economic Justice, 1966. United States Government Printing Office, Washington D.C.

Kirkpatrick, N., 2020. From the Executive Director - | OhioNET [WWW Document]. URL https://www.ohionet.org/blog/2020/06/executive-director-\%E2\%80\%94 (accessed 6.30.20).

Lang, C., 2020. Asian Americans' Response to Black Lives Matter Is Part of a Complicated History. Time.

LaRue, J., 2018. Library Meeting Rooms for All. Intellectual Freedom Blog. URL https://www.oif.ala.org/oif/?p=14997 (accessed 6.30.20).

Link, B.G., Phelan, J., 1995. Social Conditions As Fundamental Causes of Disease. Journal of Health and Social Behavior 35, 80. https://doi.org/10.2307/2626958

Mudrock, T., 2020. Library Guides: Racial Justice Resources: Campus Resources \& Responses [WWW Document]. URL https://guides.lib.uw.edu/racial-justice/campusresources (accessed 6.30.20).

Oakland Public Library Racial Equity Team, 2020. A Letter to Oakland | Oakland Public Library [WWW Document]. URL https://oaklandlibrary.org/news/2020/06/letter-oakland (accessed 6.30.20).

O’Dowd, P., Hagan, A., 2020. Black Lives Matter Movement Resonates Across Africa. WBUR. Palmer, B., Wessler, S., 2018. The Costs of the Confederacy. Smithsonian Magazine.

Phenix, K.J., McCook, K., 2005. Human rights and librarians. Reference \& User Services Quarterly 45, 23-25.

Poon, L., 2020. Coronavirus Tests the Limits of America's Public Libraries. Bloomberg.com. 
Price, G., 2020. Statements From Libraries and Library Organizations Re: Racism and Increased Violence [WWW Document]. LJ infoDOCKET. URL https://www.infodocket.com/2020/06/01/statements-from-library-organizations-reracism-and-increased-violence/ (accessed 6.30.20).

Rally held in central Seoul to support Black Lives Matter movement [WWW Document], 2020. . Yonhap News Agency. URL https://en.yna.co.kr/view/AEN20200606002800325

Ray, V., 2019. A Theory of Racialized Organizations: American Sociological Review. https://doi.org/10.1177/0003122418822335

Regan, H., Watson, A., Walsh, C., 2020. In Australia, protesters demand justice over minority deaths in custody. $\mathrm{CNN}$.

revoke the Library of the Year 2020 award [WWW Document], n.d. . Google Docs. URL https:/docs.google.com/document/d/1oZTn0gQAW88o3W5KxFQJwRIY4LXIyqjfY0yyJCvBEE/edit?usp=sharing\&usp=embed_facebook (accessed 6.30.20).

Rosenbaum, L., 2020. Johns Hopkins Changed Its Guidance On Re-Opening The Economy After Pushback From Librarians. Forbes.

Sellie, A., 2020. Black Lives Matter. Graduate Center Library Blog. URL https://gclibrary.commons.gc.cuny.edu/2020/06/01/blm/ (accessed 6.30.20).

Taylor, D.B., 2020. George Floyd Protests: A Timeline. The New York Times.

Thousand Currents, n.d. Black Lives Matter - Thousand Currents. URL https://thousandcurrents.org/black-lives-matter/ (accessed 6.30.20).

Werner, E., DeBonis, M., 2020. Worried that \$2 trillion law wasn't enough, Trump and congressional leaders converge on need for new coronavirus economic package. Washington Post.

Westbrooks, E., 2020. The University Libraries' Role in Reckoning with Systemic Racism and Oppression - UNC Chapel Hill Libraries [WWW Document]. URL https://library.unc.edu/2020/06/the-university-libraries-role-in-reckoning-with-systemicracism-and-oppression/ (accessed 6.30.20).

Westerman, A., King, N., Kwong, M., 2020. For One Immigrant Community, George Floyd's Death Isn't Just About Black And White. NPR.org.

Wiesel, E., 1986. Nobel Prize Speech. Elie Wiesel Foundation for Humanity. URL https://eliewieselfoundation.org/elie-wiesel/nobelprizespeech/ (accessed 6.28.20).

Yang, J., 2020. It's time for Asian Americans to unite in solidarity with black Americans [WWW Document]. CNN. URL https:/www.cnn.com/2020/06/05/opinions/tou-thaoasian-american-solidarity-with-black-americans-yang/index.html 